\title{
Effect of Moringa seed meal as a feed additive on performance of fattening male Barki sheep
}

\author{
Dalia KA EL-Hedainy, Eman El-Wakeel and AMA Rashad* \\ Department of Animal and Fish Production, Faculty of Agriculture, Alexandria University, Egypt
}

Received: 01 December, 2020

Accepted: 22 December, 2020

Published: 23 December, 2020

*Corresponding author: AMA Rashad, Department of Animal and Fish Production, Faculty of Agriculture, Alexandria University, Aflaton Street, El-Shatby, Postal Code 22545, Alexandria, Egypt, Tel: 00203 3322915; Fax: 00203 5922780;

E-mail:amr_rashad43@yahoo.com

Keywords: Moringa oleifera; Barki sheep; Body weight; Body measurements; Blood biochemical parameters

https://www.peertechz.com

Check for updates

\begin{abstract}
Moringa Oleifera Lam. is a tree native to the Indian subcontinent and has been naturalized in various tropical and subtropical areas around the world. The fresh leaves, flowers and pods are consumed for human feeding, while may also use in livestock feeding. Many researchers evaluated the effects of using Moringa Oleifera parts as additive to farm animals feed on feed intake, and digestibility and found that it may had positive effects on them. The main goal of this experiment was to appraise the effects of using Moringa seeds as a feed additive on growth performance, body measurements and blood biochemistry of fattened Barki sheep. Thirty 5-months old male Barki lambs were choosed randomly from the fattening research herd of Faculty of Agriculture, Alexandria University for this study. Lambs had $25.3+0.9 \mathrm{~kg}$ average initial live weight were involved in two groups each of 15 heads and fed according to NRC 2001. The first group (control) fed on concentrate commercial mixture (14\% total protein and $65 \%$ total digestible nutrient) with no Moringa seed meal added. The second group (MSM) fed the same concentrate mixture supplemented with $4 \mathrm{~g}$ of Moringa seed per day/head. Lambs body weights were recorded at the beginning of the trial, and then every 15-days throughout the experiment which lasted 45 days. Similarly, measures of body length, height at wither, chest girth and round circumference were recorded along with body weights. The average final body weight of control lambs $(31.5+1.6 \mathrm{~kg})$ was less $(P<0.001)$ than that of MSM group $(34.5+1.4 \mathrm{~kg})$, similarly the daily gain was significantly more $(P<0.05)$ with MSM group $(0.276+0.1 \mathrm{~g})$ than control group $(0.138+0.1 \mathrm{~g})$. The corresponding body measurements were not significantly different in control than MSM group. The supplement to diet of lamb fattened lambs increased total protein concentration in the blood $(5.63 \pm 0.16 \mathrm{mg} / \mathrm{dL})(P=0.01)$ compared to the control $(5.15 \pm 0.08 \mathrm{mg} / \mathrm{dL})$. Also, all components of blood serum which were within the normal range, indicating that it is safe to use Moringa seeds.
\end{abstract}

\section{Abbreviation}

MSM: Moringa Seed Meal; IW: Initial Weight; IM: Initial Measurements; TG: Triglyceride; AST: Aspartate Aminotransferase; ALT: Alanine Aminotransferase

\section{Introduction}

Moringa Oleifera Lam., is a tree native to the Indian subcontinent and has been naturalized in various tropical and subtropical areas around the world. It is known regionally as Benzolive, Drumstick, Horseradish, Kelor, Marango, Mlonge, Mulangay, Saijihan or Sajna trees [1]. It thrives best under the tropical climate and grows well in the humid tropics or hot dry lands but can also survive in low fertile soils and little affected by drought [2]. The tree is one of the world's most useful plants, as every part of it can use for food, remedy or manufacturing goals [3]. The fresh leaves, flowers and pods are consumed for human feeding, while may also use in livestock feeding [4]. Although different parts like leaves and seeds of Moringa have been experimented for use as feeds or additives to livestock rations, little is known in Egypt about potentials of feeding Moringa on performance of sheep and other animals like chicken and mouth. In 2011, Zanu, et al. [5] tested the effects of the partial replacement of fishmeal with Moringa leaves on broiler chickens and reported better growth performance, carcass characteristics, hematological properties, serum biochemical parameters and meat quality without any effects on health or feed costs. Ben Salema and Makkarb [6] evaluated the effects of using defatted Moringa Oleifera seed as additive to Barbarine lambs' fed oat-vetch hay based diet on feed intake, digestibility and growth performance and found that incorporating up to $4 \mathrm{~g}$ seeds/day had positive effects on them.

The main goal of this experiment was to appraise the effects of using Moringa seeds as a feed additive on growth performance, body measurements and blood biochemistry of fattened Barki sheep. 


\section{Materials and methods}

\section{Preparation of moringa meal}

Seeds were obtained from Moringa Oleifera Lamarck trees cultivated locally in a commercial farm. The seeds were sun dried, packaged in double layers plastic bags (1.5 kg Moringa seeds/bag) and stored at $4 \mathrm{C}$ until use. The whole seeds with kernels and shells were ground to pass a 1-mm sieve, then packed into doses of $60 \mathrm{~g}$ each ( $4 \mathrm{~g}$ of MSM x 15 lamb / day) and used as feed additive.

\section{Animals, diet and treatments}

Thirty 5-months old male Barki lambs averaged 25.3+0.9 $\mathrm{kg}$ live body weight were choosed randomly from the fattening research herd of Agriculture Research Station of Faculty of Agriculture, Alexandria University were used in this study. Lambs were kept outdoors with shelter during the day and housed in a semi-open barn at night. Animals were clinically normal, diseases-free and had healthy appearance. Before the commencement of the experiment, lambs were injected against internal parasites using Ivomec and then randomly divided into two groups (control and MSM) each of 15 lambs, given 2 weeks for adaptation on experimental conditions. Lambs were fed according to NRC [7] requirements on commercial concentrate mixture (14\% TP and $65 \% \mathrm{TDN})$ and ad libitum roughage (alfalfa hay). The control lambs were fed on the experimental rations without additives while treated lambs received $4 \mathrm{~g}$ MSM/day/head as additive (this level was tested by Ben Salema and Makkar [6]), where they used three levels of Moringa seeds for fattening sheep, which were 2, 4 and $6 \mathrm{~g}$ Moringa oleifera seed per day per head and found that the medium level gave the highest rates of growth). Water was available to all animals at all times. Lambs Initial Weight (IW) was recorded at the beginning of the experiment (day 0 , the real day when the animals started the experiment) then consecutive weights were obtained at 15 days intervals (day 15, 30 and 45). All weights, except birth weight, were recorded early in the morning after a $12 \mathrm{~h}$ fasting period. Similarly initial measurements (IM) of body length, height at wither, chest girth and round circumference were taken as described by Fisher [8] at the day of weighing. Blood samples were taken randomly from 10 lambs of each group at the end of the trial to determine; total protein by the Biuret method as described by Armstrong and Carr [9], albumin by the bromocresol green method of Doumas, et al. [10], urea, glucose according to Barham and Trinder [11], cholesterol as described by Watson [12], Triglyceride (TG), Aspartate Aminotransferase (AST) and Alanine Aminotransferase (ALT) were measured calorimetrically as described by Reitman and Frankel [13] in blood plasma.

\section{Statistical analysis}

Data analyzed statistically by GLM procedure of SAS [14]. Duncan's multiple range tests was performed to compare between means at the level of significant $P<0.05$. The following model was assumed to describe each dependent variable of the final body weight or measurements: $Y_{\mathrm{ijk}}=\mu+\mathrm{G}_{\mathrm{i}}$ $+\mathrm{b}_{\mathrm{j}}(\mathrm{x}-\bar{x})+\mathrm{e}_{\mathrm{ijk}}$, Where: $\mathrm{Y}_{\mathrm{ijk}}=$ an observation of each dependent trait, $\mu=$ the overall mean, $G_{i}=$ the effect of the feeding group, $b_{i}=$ a regression coefficient of the trait on Initial Weight (IW) or Initial Measure (IM), $\mathrm{x}=$ the independent continuous variate for (IW) or (IM), $\bar{x}=$ the respective mean, and $\mathrm{e}_{\mathrm{ijk}}=$ the random error term associated with each observation and assumed independent, normally distributed with mean zero and variance $\delta^{2} \mathrm{e}$

Mean while, the effects of feeding group, time span and their interaction on daily body weight gain and daily change in body measurements were analyzed according to the following model: $Y_{i j k}=\mu+G_{i}+T_{j}+(G \times T)_{i j}+e_{i j k}$, where: $Y_{i j k}=a n$ observation on each of the studied traits, $\mu=$ the overall mean, $G_{i}=$ the effect of the $i^{\text {th }}$ feeding group, $T_{j}=$ the effect of the $j^{\text {th }}$ time span, $(\mathrm{G} \mathrm{x} \mathrm{T})_{\mathrm{ij}}=$ the interaction between the $\mathrm{i}^{\text {th }}$ group and the $j^{\text {th }}$ time, $e_{i j \mathrm{k}}=$ the random error term associated with each observation.

For testing the effect of Moringa seeds on blood biochemical parameters, the following model was used: $Y_{i j k}=\mu+G_{i}+e_{i j}$, where: $Y_{i j k}=$ an observation of each blood parameter, $\mu=$ the overall mean, $G_{i}=$ the effect of the $i^{\text {th }}$ feeding group, $e_{i j}=$ the random error term associated with each observation.

\section{Results}

Least squares means and standard errors of body weight, body measurements and daily gain or change of MSM and control lambs groups are presented in Tables 1,2. The final body weight of control group at the end of fattening period $(31.5+1.6 \mathrm{~kg})$ was less $(P<0.001)$ than that of the MSM group $(34.5+1.4 \mathrm{~kg})$. Similarly, the daily gain of the control group was lower $(P<0.05)$ than that of MSM $(0.138+0.1 \mathrm{~g}$ and $0.276+0.1$ $\mathrm{g}$, respectively). All body measurements of the control lambs and their daily change though were slightly higher than those of MSM lambs, except for the height at wither and average change in chest girth and height at wither but the differences were not reach the significant level.

Table 1: Least square means $( \pm$ S.E) of body weight $(\mathrm{kg})$ and body measurements (cm) of lambs fed diet supplemented with Moringa seed meal (MSM) compared to control diet (control)

\begin{tabular}{|c|c|c|c|}
\hline \multirow{2}{*}{ Traits } & \multicolumn{3}{|c|}{ Treatment } \\
\cline { 2 - 4 } & Control & MSM & Reg. $^{*}$ \\
\hline Body weight, $\mathrm{kg}$ & $31.49 \pm 1.61$ & $34.39 \pm 1.36$ & 0.001 \\
\hline Body length, cm. & $63.05 \pm 0.92$ & $61.19 \pm 0.81$ & 0.611 \\
\hline Height at wither, cm. & $67.11 \pm 1.53$ & $67.76 \pm 1.34$ & 0.102 \\
\hline Girth chest, cm. & $81.15 \pm 1.66$ & $81.11 \pm 1.45$ & 0.011 \\
\hline Round circumference, cm. & $26.79 \pm 1.10$ & $26.09 \pm 0.97$ & 0.856 \\
\hline
\end{tabular}

* Reg., the $P$-value of the regression on initial weights or measures

Table 2: Least square means $( \pm S . E)$ of daily weight gain $(\mathrm{kg})$ and daily body measurements change $(\mathrm{cm})$ of lambs fed diet supplemented with Moringa seed meal (MSM) compared to control diet (control).

\begin{tabular}{|c|c|c|c|}
\hline \multirow{2}{*}{ Traits } & \multicolumn{3}{|c|}{ Treatment } \\
\cline { 2 - 4 } & Control & MSM & $P$-value \\
\hline Body weight gain, $\mathrm{kg} / \mathrm{d}$ & $0.138 \pm 0.050^{\mathrm{b}}$ & $0.276 \pm 0.046^{\mathrm{a}}$ & 0.045 \\
\hline Body length change, $\mathrm{cm} / \mathrm{d}$ & $0.172 \pm 0.082$ & $0.113 \pm 0.076$ & 0.601 \\
\hline Height at wither change, $\mathrm{cm} / \mathrm{d}$ & $0.154 \pm 1.151$ & $0.173 \pm 1.068$ & 0.990 \\
\hline Girth chest change, $\mathrm{cm} / \mathrm{d}$ & $0.080 \pm 0.047$ & $0.113 \pm 0.044$ & 0.621 \\
\hline Round circumference change, $\mathrm{cm} / \mathrm{d}$ & $0.016 \pm 0.055$ & $0.001 \pm 0.051$ & 0.828 \\
\hline a-b Means with different letters in the same column within each trait differ $(P<0.05)$
\end{tabular}

Citation: EL-Hedainy DK, El-Wakeel E, Rashad AMA (2020) Effect of Moringa seed meal as a feed additive on performance of fattening male Barki sheep. Int J Vet 
Least square means of experimental time increment for weight gain $(\mathrm{kg})$ and body measurers changes $(\mathrm{cm})$ of control and MSM lambs groups are presented in Table 3 and Figure 1. Change in all body measurements were high $(P<0.001)$ in the first two weeks of the experiment in the two groups than the second and third periods except chest girth, which was high in the second period $(0.383 \mathrm{~cm})$ but meager otherwise $(0.103$ and $0.10 \mathrm{~cm}$, respectively). Also, body weight gain was greater $(P<0.001)$ during the first two weeks in the two groups $(0.402$ $\mathrm{kg})$ than in the second and third periods $(0.122$ and $0.097 \mathrm{~kg}$, respectively). The extended use of MSM resulted in a decreasing trend in daily gain of body weight from $635 \mathrm{~g} / \mathrm{d}$ in the first two weeks to $88 \mathrm{~g} / \mathrm{d}$ at the end of the experiment. The end complementary work is needed to test the effect of prolonged use of MSM on daily gain of sheep.

Table 3: Least square means ( $\pm S$.E) of the experimental time increment effect on weight gain $(\mathrm{kg})$ and body measurers change $(\mathrm{cm})$ of lambs fed diet supplemented or un-supplemented with Moringa seed meal.

\begin{tabular}{|c|c|c|c|c|c|}
\hline \multirow{2}{*}{ Traits } & \multicolumn{3}{|c|}{ Time, d } & \multicolumn{2}{c|}{ P-value } \\
\cline { 2 - 6 } & $\mathbf{0 - 1 5}$ & $\mathbf{1 5 - 3 0}$ & $\mathbf{3 0 - 4 5}$ & Time & $\begin{array}{c}\text { Group* } \\
\text { Time }\end{array}$
\end{tabular}

\begin{tabular}{lllll|l}
\hline Body weight gain, $\mathrm{kg} / \mathrm{d} \quad 0.402 \pm 0.057^{\mathrm{a}}$ & $0.122 \pm 0.059^{\mathrm{b}}$ & $0.097 \pm 0.061^{\mathrm{c}}$ & 0.001 & 0.001
\end{tabular} Body length change, $\mathrm{cm} / \mathrm{d}$

$0.259+1.308 \quad 0.185+0.097 \quad 0.016+0.100 \quad 0.128 \quad 0.981$

Height at wither

change, $\mathrm{cm} / \mathrm{d}$

Girth chest change,

$\mathrm{cm} / \mathrm{d}$

Round circumference

change, $\mathrm{cm} / \mathrm{d}$

\begin{tabular}{l|l|l|l|l}
$0.103 \pm 0.045^{\mathrm{b}}$ & $0.383 \pm 0.056^{\mathrm{a}}$ & $0.010 \pm 0.058^{\mathrm{c}}$ & 0.002 & 0.001
\end{tabular}

\begin{tabular}{l|l|l|l|l|l}
$0.122 \pm 0.062^{\mathrm{a}}$ & $0.036 \pm 0.065^{\mathrm{b}}$ & $0.108 \pm 0.067^{\mathrm{a}}$ & 0.041 & 0.317
\end{tabular}

Means with different letters in the same column within each trait differ $(P<0.05)$
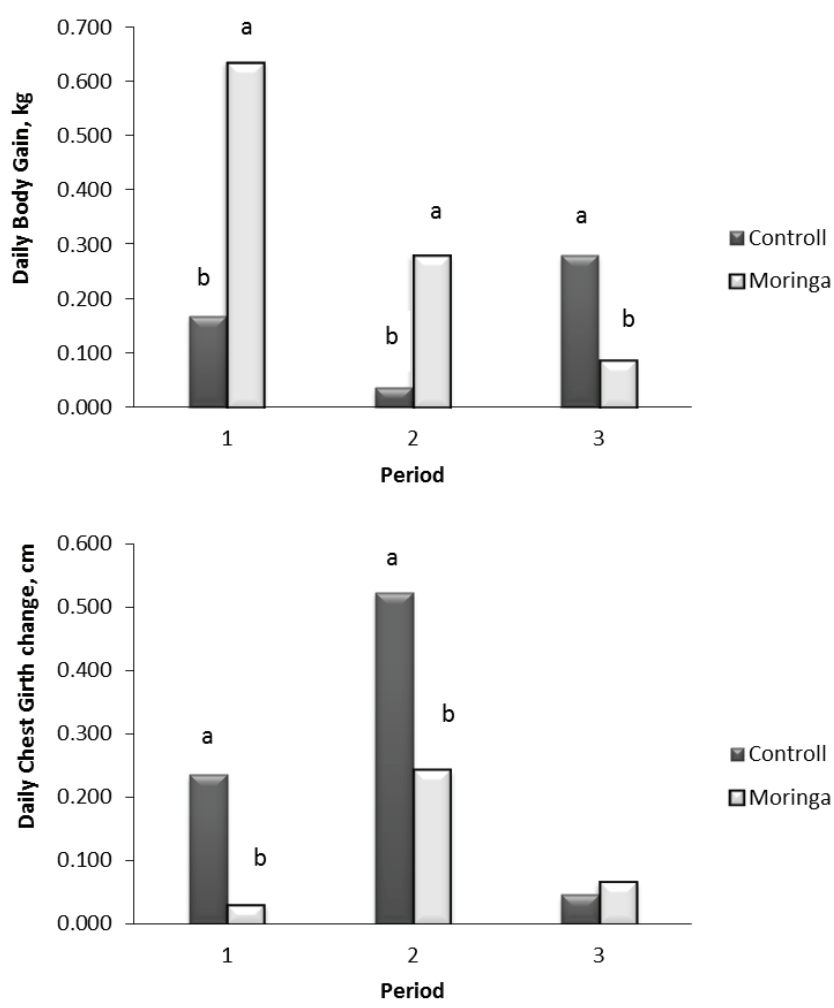

Figure 1: The effect of using Moringa seeds as a feed additive comparing to control at the same period $(0-15,15-30$ and $30-45 \mathrm{~d})$ on daily body weight gain and chest girth change of lambs
Least square means of blood biochemical constituents of the control group and MSM are presented in Table 4. Supplementing diets of fattening lambs with MSM increased $(P=0.01)$ blood serum total protein concentrations $(5.63+0.16$ $\mathrm{mg} / \mathrm{dL})$ compared to control $(5.15+0.08 \mathrm{mg} / \mathrm{dL})$. However, no differences were obtained in all blood serum constituents of albumin, urea, glucose, cholesterol, triglycerides, ALT and AST between control and MSM lambs (Table 4).

Table 4: Least square means $( \pm S$.E) of blood biochemical parameters of lambs fed diet supplemented with Moringa seed meal (MSM) compared to control diet (control).

\begin{tabular}{|c|c|c|c|}
\hline Item & Control & MSM & P-value \\
\hline Total Protein & $5.15 \pm 0.08^{\mathrm{b}}$ & $5.63 \pm 0.16^{\mathrm{a}}$ & 0.01 \\
\hline Albumin & $4.25 \pm 0.15$ & $3.91 \pm 0.12$ & 0.14 \\
\hline Urea & $3.75 \pm 0.17$ & $3.52 \pm 0.19$ & 0.43 \\
\hline Glucose & $61.94 \pm 2.63$ & $59.83 \pm 1.87$ & 0.54 \\
\hline Cholesterol & $131.46 \pm 2.73$ & $134.88 \pm 5.06$ & 0.55 \\
\hline TG & $70.89 \pm 3.05$ & $73.06 \pm 2.72$ & 0.63 \\
\hline ALT & $79.29 \pm 1.13$ & $77.55 \pm 1.30$ & 0.32 \\
\hline AST & $189.28 \pm 1.85$ & $192.92 \pm 4.29$ & 0.40 \\
\hline
\end{tabular}

a-b Means with different letters in the same column within each trait differ $(P<0.05)$ TG: Triglyceride; AST: Aspartate Aminotransferase; ALT: Alanine Aminotransferase

\section{Discussion}

The present results of body weight and daily gain are in accordance with those cited by Ben Salema and Makkar [6] when fed the same level of MSM to weaned Barbarine male sheep. Also, Melesse, et al. [15] reported that feeding airdried Moringa stenopetala leaf compared to natural grass hay significantly increased body weight gain in Arsi-Bale goat kids. Also, all blood serum constituents are within the normal range which indicates that feeding MSM to fattening lambs is safe and exerts no detrimental effects on health or performance [16]. The concentration of blood biochemical parameters is important to assess the quality of the feed ingredients forming the rations offered to the animals [17]. Increased blood serum total protein (Table 4) of fattening lambs fed MSM compared to control lambs was associated with improved body weight gain (Table 2). It is worthy to mention that plasma ALT and AST levels are crucial indicators for liver cells integrity and functionality. Any extracellular increase of these enzymes forms a sign of liver cell degenerations and dysfunction [18]. Fortunately supplementing lambs with MSM had no adverse effects neither on blood biochemical concentrates nor on hepatic enzymes. In addition to MSM, Moringa leaves were found to have good impacts on rumen un-degradable protein which result in improved protein availability for utilization [19]. Moreover, MSM are good source of protein which may efficiently replace soybean and rapeseed meals in ruminant rations and improve microbial protein formation in the rumen [20]. More work to evaluate the potential of including Moringa seed meal in formulating fattening lambs diets is important and may reduce fattening cost.

Citation: EL-Hedainy DK, El-Wakeel E, Rashad AMA (2020) Effect of Moringa seed meal as a feed additive on performance of fattening male Barki sheep. Int J Vet Sci Res 6(2): 184-187. DOl: https://dx.doi.org/10.17352/ijvsr.000072 


\section{Animal rights statement}

All animal studies are conducted in accordance with the ethical standards of animal rights of Egyptian law and international agreements.

\section{Author contributions}

- Dalia, K.A. EL-Hedainy: paper idea, collecting data, collecting references, writing the manuscript.

- Eman El-Wakeel: paper idea, blood samples taken and analysis, writing the manuscript.

- M. A. Rashad: paper idea, collecting data, data statistical analysis, writing the manuscript.

\section{References}

1. Fahey JW (2005) Moringa Oleifera: A review of the Medical evidence for its nutritional, Therapeutic and prophylactic properties. Part 1. Link: http://bit.ly/34vGCmH

2. Anwar F, Sajid L, Muhammad A, Anwarul HG (2007) Moringa Oleifera: A Food plant with Multiple Medicinal Uses. Phytother Res 21: 17- 25. Link: http://bit.ly/2KhVCxJ

3. Khalafalla MM, Abdellatef E, Dafalla HM, Nassrallah AA, Aboul-Enein KM, et al. (2010) Active principle from Moringa Oleifera Lam leaves effective against leukemia and a hepatocarcinoma. African Journal of Biotechnology 9: $8467-$ 8471. Link: http://bit.ly/2Ja5Hfl

4. Anjorin TS, Ikokoh P, Okolo S (2010) Mineral composition of Moringa Oleifera leaves, pods and seeds from two regions in Abuja, Nigeria. Internationa Journal of Agriculture Biology 12: 431-434. Link: https://bit.ly/37Defoq

5. Zanu HK, Asiedu P, Tampuori M, Abada M, Asante I (2012) Possibilities of using Moringa (Moringa Oleifera) leaf meal as a partial substitute for fishmeal in broiler chickens diets. Journal of Animal Feed Research 2: 70-75. Link: https://bit.ly/3mG5jD9

6. Ben Salema H, Makkarb HPS (2009) Defatted Moringa Oleifera seed meal as a feed additive for sheep. Animal Feed Science Technology 150: 27-33. Link: http://bit.ly/2KvwEe5

7. NRC (national research council) (2001) Nutrient requirements of beef cattle. National Academy Press, Washington, DC.

8. Fisher AV (1976) Live animal measurements as a means of evaluating animals in beef production experiments. In seminar on criteria and methods for assessment of carcass and meat characteristics in beef production Experiments, zeist, Holland.

9. Armstrong WD, Carr CW (1964) Physiological Chemistry Laboratory Directions 3rd ed. Burges Publishing Co., Minneapolis, MN

10. Doumas BT, Watson WA, Biggs HG (1977) Albumin standards and the measurement of serum albumin with bromocresol green. Clinica Chimica Acta $31: 87-96$

11. Barham D, Trinder $P$ (1972) An Improved colour reagent for determination of blood glucose by oxidase system. Analyst 44: 223-231. Link: http://bit.ly/3rlHMLm

12. Watson $D$ (1960) A simple method for the determination of serum cholesterol Clin Chim Acta 5: 637-638. Link: http://bit.ly/3rhzJ1X
13. Reitman S, Frankel S (1957) A colorimetric method for the determination of serum glutamic oxaloacetic pyruvic transaminases. Am J Clin Pathol 28 56-63. Link: http://bit.ly/3aF5D2N

14. SAS (Statistical Analysis System User's Guide) (2004) SAS Institute, Inc., Cary, version 9. North Carolina, USA. Link: https://bit.ly/2MOvsQr

15. Melesse A, Meskel DH, Banerjee S, Abebe A, Sisay A (2015) The effect of supplementing air-dried Moringa stenopetala leaf to natural grass hay on feed intake and growth performances of Arsi-Bale Goats. Agriculture 5: 11831194. Link: http://bit.ly/3retQTn

16. Dimauro C, Macciotta NP, Rassu SP, Patta C, Pulina G (2009) A bootstrap approach to estimate reference intervals of biochemical variables in sheep using reduced sample sizes. Small Ruminant Research 83: 34-41. Link: https://bit.ly/3azamTy

17. Maxwell MH, Robertson GW, Spences S, McCongrouodala CC (1990) Composition of haematological values in restricted and ad libitum feed domesticated fowls. RBC Characteristics. Br Poult Sci 60: 1474-1484. Link: http://bit.ly/2WC4uR7

18. Peltenburg HG, Hermens WT, Willems GM, Flendrig JG, Schmidt E (1989) Estimation of the fractional catabolic rate constants for the elimination of cytosolic liver enzymes from plasma. Hepatology 10: 833-839. Link: http://bit.ly/3rmQN6C

19. Garg SK, Makkar HPS, Nagal KB, Sharma SK, Wadhwa DR, et al. (1992) Oak (Quercus incana) leaf poisoning in cattle. Vet Hum Toxico 34: 161-164. Link: http://bit.ly/34zvx47

20. Soliva CR, Kreuzer M, Foidl N, Foidl G, Machmüller A, et al. (2005) Feeding value of whole and extracted Moringa oleifera leaves for ruminants and their effects on ruminal fermentation in vitro. Animal Feed Science and Technology 118: 47-62. Link: http://bit.ly/2KsVFXh

\section{Discover a bigger Impact and Visibility of your article publication with}

\section{Peertechz Publications}

\section{Highlights}

* Signatory publisher of ORCID

* Signatory Publisher of DORA (San Francisco Declaration on Research Assessment)

- Articles archived in worlds' renowned service providers such as Portico, CNKI, AGRIS, TDNet, Base (Bielefeld University Library), CrossRef, Scilit, J-Gate etc.

* Journals indexed in ICMJE, SHERPA/ROMEO, Google Scholar etc.

* OAI-PMH (Open Archives Initiative Protocol for Metadata Harvesting)

* Dedicated Editorial Board for every journal

* Accurate and rapid peer-review process

* Increased citations of published articles through promotions

* Reduced timeline for article publication

Submit your articles and experience a new surge in publication services (https://www.peertechz.com/submission).

Peertechz journals wishes everlasting success in your every endeavours.

Copyright: @ 2020 EL-Hedainy DK, et al. This is an open-access article distributed under the terms of the Creative Commons Attribution License, which permits unrestricted use, distribution, and reproduction in any medium, provided the original author and source are credited.

Citation: EL-Hedainy DK, El-Wakeel E, Rashad AMA (2020) Effect of Moringa seed meal as a feed additive on performance of fattening male Barki sheep. Int J Vet Sci Res 6(2): 184-187. DOI: https://dx.doi.org/10.17352/ijvsr.000072 